\title{
Studies on Effect of Propagation Environment for Softwood Grafting in Guava (Psidium guajava L.) cv. Sardar
}

\author{
B. Manga*, P. Jholgiker, G.S.K. Swamy, G. Prabhuling and N. Sandhyarani \\ Department of Fruit science, KRCCH, Arabhavi, University of Horticultural Sciences, \\ Bagalkot, Karnataka, India \\ *Corresponding author
}

\section{A B S T R A C T}

\begin{tabular}{|l|}
\hline Ke y w o r d s \\
Guava, Mist \\
house, Poly house, \\
Shade house, \\
polytunnel.
\end{tabular}

Keywords

Guava, Mist house, Poly house, Shade house, polytunnel.

\section{Introduction}

Guava is considered as one of the exquisite and nutritionally valuable fruit crops. It excels most other fruit crops in productivity, hardiness, adaptability and nutritive value. Besides its high nutritive value, it bears heavy crop every year and gives good economic returns involving very little input (Singh, 2007). Most of guava plantations in India are seedling origin. Traditionally, it is mostly propagated from seed (Zamir et al., 2003). However, plants raised from seeds are not true to type and eventually take longer time to reach to bearing stage. They are also propagated by layering, however it is combursome and has limitation for large scale and rapid multiplication. Softwood grafting, which is successfully practiced in fruit crops like mango, sapota cashew, jack fruit with good response can also be practice in guava. This method is easy, convenient in handling, involves simple skill and takes short period. The most important feature of the method is that, it allows higher rate of multiplication of plants and resultant plants will be vigorous. The propagation environment for grafting is one of the most important factors which plays a key role in success of grafting. The year round fluctuation in temperature, relative humidity and sunlight results in varying degree of success in softwood grafting in 
guava. Identification of right type of propagation structure with ideal micro climate conditions suitable for softwood grafting will help in rapid multiplication and production of healthy planting material.

Limited work has been done and reported in guava with respect to improvement in graft success by using controlled conditions / propagation environment. There is a need to identify right type of propagation environment for higher propagation efficiency. Therefore, the present investigation was undertaken.

\section{Materials and Methods}

An experiment, on studies on effect of propagation environment for softwood grafting in guava (Psidium guajava L.) cv. Sardar was carried out during the period from October 2012 to December 2012, at the Department of Fruit Science, Kittur Rani Channamma College of Horticulture, Arabhavi, University of Horticultural Sciences, Bagalkot, Karnataka state. The experiment was conducted to find out the influence of propagation environment on success of softwood grafting in guava. The experiment was laid out in Randomized Block Design with 5 treatments and 5 replications. Softwood wedge grafting was performed in the month of October. Two fifty grafts were prepared at the rate of fifty grafts in each treatment and placed under different environments viz., open condition, shade house, poly house, mist house and poly tunnel.

Root stocks were raised in poly bags from fresh seeds of guava cv. 'Sardar' extracted from ripe fruits for approximately 6 to 8 months till they attained a stem diameter of 0.5 to $1.0 \mathrm{~cm}$. The scion shoots $(15$ to $18 \mathrm{~cm}$ long) of pencil size thickness with 3 to 4 healthy buds were used for grafting. Selected scion shoots were pre-cured ten days prior to detachment. Softwood wedge grafting was performed in the month of October as per procedure suggested by Amin (1974). The prepared grafts were covered from top by polytube cap. This cap was retained on the graft for one month or till sprouting was observed on the graft. The observation were recorded on graft-take i.e. per cent graft success and survival percentage. The growth parameters such as number of sprouts, per cent sprouting, average length of sprout and average number of leaves were recorded at 30, 60 and 90 days after grafting. The data was statistical analysed by following procedure as suggested by Panse and Sukhatme (1978).

\section{Results and Discussion}

The data pertaining to the studies on effect of different propagation environment on graft take in softwood grafting of guava cv. Sardar demonstrated varying degree of success (Table 1). Interpretation of data indicated maximum per cent graft success $(62.00 \%)$ was recorded in graft kept under mist house eco system followed by shade house $(48.00$ $\%)$ and lowest grafting success was recorded in poly tunnel $(10.00 \%)$ at 90 days after grafting respectively.

Results of data reveal significant differences for graft survival in different propagation environment. The significantly maximum graft survival $(97.14 \%)$ was recorded in grafts placed under mist followed by grafts under the shade house condition $(95.00 \%)$ at 90 DAG, which were at par with each other (Table 1). The superiority of propagation with the help of mist house has been well documented by Muniswami (1979) in cashew, Raghavendra et al., (2011) in wood apple and Rajashekar (1999) in sapota. The beneficial effects of high graft success for softwood grafting under mist house could be attributed 
to availability of high humidity (Fig. 2) stretched for longer period which prevents desiccation of the tissues at scion and stock interface also favours rapid callus tissues development leading to better graft union formation.

Similar findings were also reported by Jose and Valsalakumari (1991) in Jack. Least graft success and survival was noticed in the polytunnel. This may be attributed to buildup of higher temperature under poly tunnel during graft healing period which might have lead to faster desiccation of fragile callus cells as these parenchymatous cells are thin walled with no provision for resisting higher temperature (Fig. 1).

Table.1 Effect of different propagation environment on graft-take and its growth at 90

DAG in softwood grafting of guava cv. Sardar

\begin{tabular}{|c|c|c|c|c|c|c|}
\hline $\begin{array}{l}\text { Propagation } \\
\text { environment }\end{array}$ & $\begin{array}{l}\text { Per cent graft } \\
\text { success }\end{array}$ & $\begin{array}{c}\text { Number } \\
\text { of } \\
\text { sprouts }\end{array}$ & $\begin{array}{l}\text { Per cent } \\
\text { sprouting }\end{array}$ & $\begin{array}{c}\text { Average } \\
\text { length of } \\
\text { sprout }(\mathrm{cm})\end{array}$ & $\begin{array}{c}\text { Average } \\
\text { number of } \\
\text { leaves }\end{array}$ & $\begin{array}{c}\text { Survival } \\
\text { percentage }\end{array}$ \\
\hline Open conditions & $\begin{array}{c}40.00 \\
(39.23)^{*}\end{array}$ & 3.88 & $\begin{array}{c}48.00 \\
(43.85)\end{array}$ & 4.76 & 20.00 & $\begin{array}{c}74.07 \\
(59.41)\end{array}$ \\
\hline Shade house & $\begin{array}{c}48.00 \\
(43.85)\end{array}$ & 3.08 & $\begin{array}{c}50.70 \\
(45.40)\end{array}$ & 4.82 & 18.00 & $\begin{array}{c}95.00 \\
(77.08)\end{array}$ \\
\hline Poly house & $\begin{array}{c}20.00 \\
(26.56)\end{array}$ & 4.40 & $\begin{array}{c}76.80 \\
(61.21)\end{array}$ & 6.12 & 20.40 & $\begin{array}{c}40.67 \\
(39.65)\end{array}$ \\
\hline Mist house & $\begin{array}{c}62.00 \\
(51.94)\end{array}$ & 4.62 & $\begin{array}{c}66.50 \\
(54.63)\end{array}$ & 6.30 & 21.60 & $\begin{array}{c}97.14 \\
(80.23)\end{array}$ \\
\hline Poly tunnel & $\begin{array}{c}10.00 \\
(18.44)\end{array}$ & 2.40 & $\begin{array}{c}55.00 \\
(47.87)\end{array}$ & 5.60 & 11.60 & $\begin{array}{c}41.67 \\
(40.23)\end{array}$ \\
\hline SEm \pm & 3.00 & 0.11 & 4.98 & 0.40 & 1.45 & 6.45 \\
\hline CD@5\% & 8.99 & 0.32 & 14.92 & 1.19 & 4.36 & 19.33 \\
\hline $\mathrm{CV}(\%)$ & 18.63 & 6.55 & 18.74 & 16.01 & 17.74 & 20.67 \\
\hline
\end{tabular}

DAG - Days after grafting

* Values in parenthesis are angular transformation data

Fig.1 Monthly average temperature $\left({ }^{\circ} \mathrm{C}\right)$ recorded in propagation structures at 8.00 am and $2.00 \mathrm{pm}$ during the period of investigation
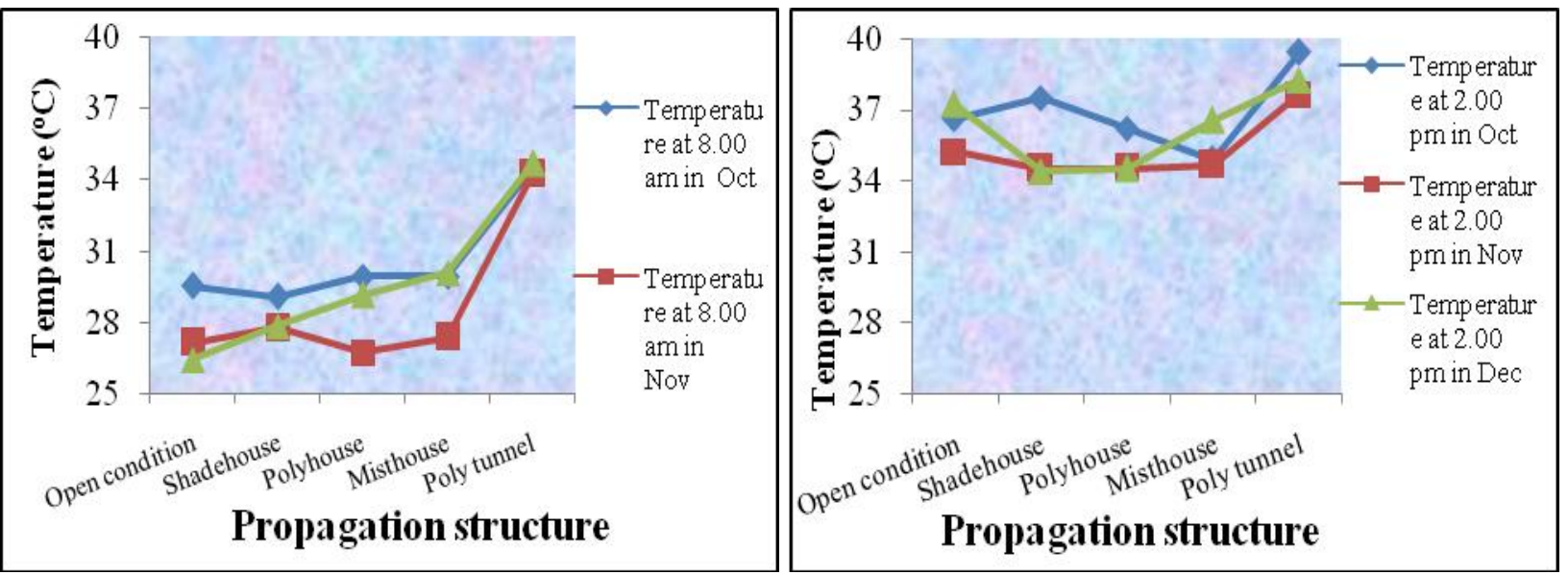
Fig.2 Monthly average relative humidity (\%) recorded in propagation structures at 8.00 am and $2.00 \mathrm{pm}$ during the period of investigation

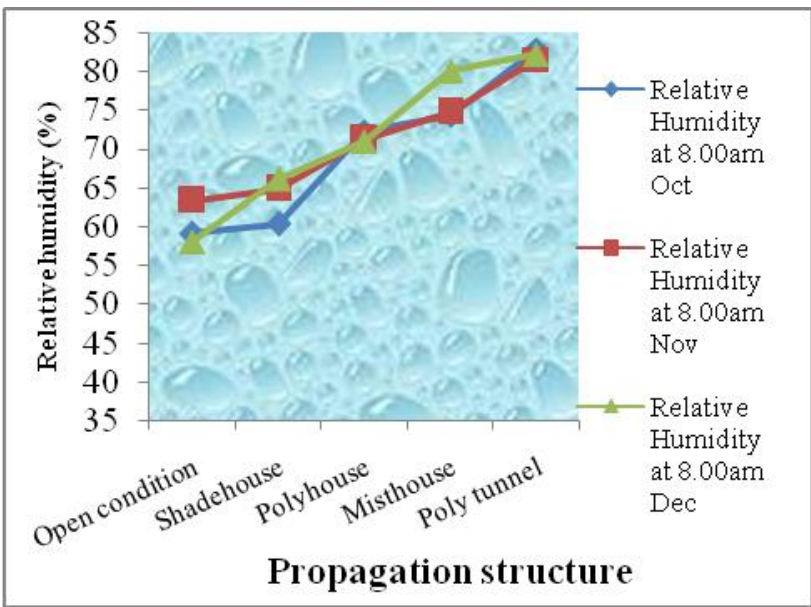

The success of graft union and its health can also be judged on the basis of production of number of sprouts, per cent sprouting, length of sprout and number of leaves (Table 1). In the present investigation the higher rate of success of graft union under mist house condition was evidenced by the higher values for growth parameters. This might be due to the high relative humidity (Fig. 2) and slightly inclined temperature prevailing in mist house ecosystem (Fig. 1).

Similar findings have also been reported by Jose and Valsakumari (1991) and Dhanraj (1996) in jackfruit. This trend was also observed by Kumar and Khan (1988) and Swami et al., (1990) in cashew, Mulla et al., (2011) in Jamun and Rajashekar (1999) in sapota.

\section{References}

Ali, Z. M. and Lazan, H. 1997. Guava In: Postharvest physiology and storage of tropical and subtropical fruits. Mitra SK (ed.) CAB international Willingford, UK, pp. 145-165.

Amin, R. S. 1974. A study on the establishment of mango orchard with wedge graft on in-situ grown mango

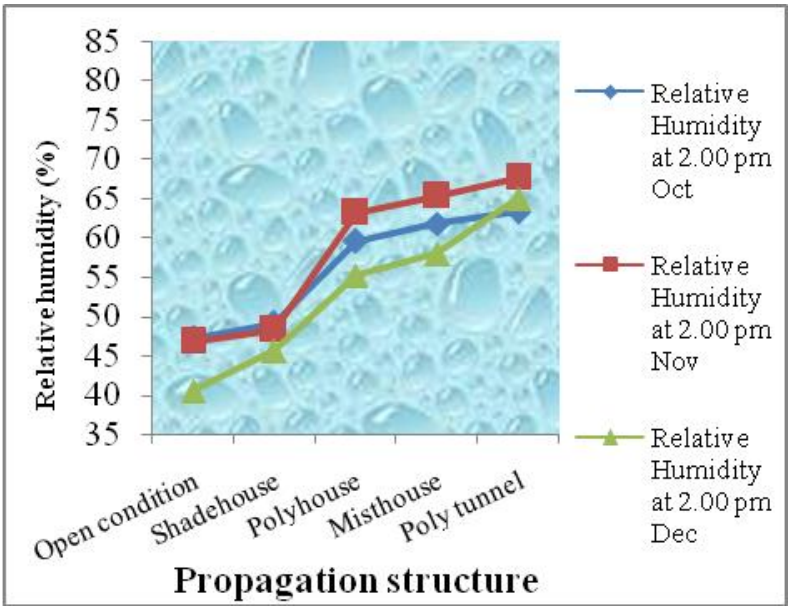

seedlings in dry region of Gujarat. Haryana J. Hort. Sci. 3: 160-167.

Anon. 2011. Area and production of guava. http//www.nhb.gov.in.

Dhanraj. 1996. Standardization of vegetative propagation techniques of jack (Artocarpus heterophyllus L.) using green house and mist chamber facilities. M. Sc. (Agri.) Thesis, Univ. Agric. Sci., Bangalore.

Kumar, B. Mistry, N. C. Singhm, B. and Gandhi, C. P. 2011. Indian Horticulture Database, National Horticulture Board (NHB), Gurgaon. Department of Agriculture and \& Cooperation, Govt. of India. Pp. 76-83.

Kumar, D. P. and Khan, M. M. 1988. In situ softwood grafting in cashew. The Cashew. 2 (2): 3-4.

Mulla, B. R. Angadi, S. G. Mathad, J. C. Patil, V. S. and Mummigatti, U. V. 2011. Studies on softwood grafting in jamun (Syzygium cumini Skeels.). Karnataka J. Agric. Sci. 24 (3): 366368.

Muniswami, K. P. 1979. Cashew grafts under mist conditions. Cashew Causerie. 1 (2): 16-20.

Panse, V. G. and Ukhatne, P. V. 1967. Statistical methods for agricultural 
workers, ICAR, New Delhi, pp. 152161.

Raghavendra, V. N. Angadi, S. G. Allolli, T. B. Venugopal, C. K. Mokashi, A. N. and Mummigatti, U.V. 2011. Studies on soft wood grafting in wood apple (Feronia limonia L.). Karnataka $J$. Agric. Sci. 24 (3): 371 - 374.

Rajashekhar, G. 1999. Studies on softwood grafting in sapota [Manilchara achras (Mill.) Fosberg] under mist house condition. M. Sc. (Hort.) Thesis, Univ. Agric. Sci. Dharwad.

Ruehle, G. D. 1948. A rapid method of propagating the guava. California Avocado Society. Yearbook. 33: 108112.

Swami, K. R. M., Singh, R. and Mohan. 1990. Correlation of success on softwood grafting in cashew with weather parameter. South Indian Hort. 38 (6): 297-300.

Valsalakumari, P. K. 1991. Standardization of the technique of epicotyl and softwood grafting in jack (Artocarpus heterophyllus Lam.). South Indian Hort. 39 (5): 264-267.

Verheij, E. W. M. and Coronel, R. E. (eds), 1991. Plant Resources of South-East Asia No. 2. Edible fruits and nuts. Backhuys Publishers, Leiden. Pp. 266270.

Zamir, R. Khattak, G. S. S., Mohammad, T. and Ali, N. 2003. In vitro mutagenesis in guava (Psidium guajava L.). Pakistan J. Bot. 35 (5): 825-828.

\section{How to cite this article:}

Manga, B., P. Jholgiker, G.S.K. Swamy, G. Prabhuling and Sandhyarani, N. 2017. Studies on Effect of Propagation Environment for Softwood Grafting in Guava (Psidium guajava L.) cv. Sardar. Int.J.Curr.Microbiol.App.Sci. 6(6): 2779-2783. doi: https://doi.org/10.20546/ijcmas.2017.606.330 